\title{
BUCKLING FORCE OF THE THIN-WALLED CROSS-SECTIONS AND SHEAR RESISTANCE OF THEIR JOINTS: TESTS AND FEM-MODELLING
}

\author{
Nikolay I. Vatin ${ }^{1}$, Jarmo Havula ${ }^{2}$, Lassi Martikainen ${ }^{3}$, Alexey S. Sinelnikov ${ }^{4}$, \\ Anna V. Orlova ${ }^{5}$, Stepan V. Salamakhin ${ }^{6}$ \\ 1,2,4,5,6 Civil Engineering Institute, Saint-Petersburg State Polytechnical University, Saint-Petersburg, Russia \\ ${ }^{3}$ HAMK University of Applied Sciences, Hämeenlinna, Finland \\ E-mail: ${ }^{1}$ vatin@mail.ru; ${ }^{2}$ jarmo.havula@hamk.fi; ${ }^{3}$ lassi.martikainen@hamk.fi; \\ ${ }^{4}$ alexey_sinelnikov@mail.ru(corresponding author); ${ }^{5} a \_v \_o r l o v a @ m a i l . r u ;{ }^{6}$ ssalamakhin@gmail.com
}

\begin{abstract}
This summary report is based on the experimental and numerical research of thin-walled cross-section compression resistance and shear strength of their joints carried out in St. Petersburg State Polytechnical University and HAMK University of Applied Sciences, Sheet Metal Centre. Current situation on the Russian market concerning the usage of cold-formed thin-walled cross-sections is aimed to find out a base foundation to start up application of the elements under discussion in the building industry (Kolesov et al. 2007; Peleshko, Urchenko 2009; Zhmarin 2012). Some questions about the compression resistance of such cross-sections were raised at different conferences (Vatin, Sinelnikov 2013; Winter 1952; Yu Wei-Wen et al. 1996) by scientific community and by companies such as Rautaruukki Oyj (Finland). Steel galvanized C- and U-profiles and thermo-profiles are types of thin-walled cross-sections that are normally used in small house construction (Shatov 2011; Smaznov 2011). Thermo-profiles have slots in webs that decrease the thermal flow through the web, but have a negative effect on strength of the profiles (Schafer, Pekoz 1998). These profiles were object of the research. Investigations carried out included tests to prove the compression resistance of the thin-walled cross-sections and shear strength of stud-to-rack joints. Numerical modelling of thin-walled cross-sections (Cheng, Schafer 2007) was done with contemporary analysis software (SCAD Office, Lira) (Kriksunov et al. 2010; Perel'muter et al. 2009) using the finite element method (FEM) (Bayan et al. 2011; Gordeeva, Vatin 2011; Rasmussen 2009).
\end{abstract}

Keywords: compression, strength, buckling analysis, self-drilling screws, reticular-stretched thermo-profiles

\section{Introduction}

Studies undertaken by the authors in the recent years have revealed that contemporary building market in Russia is looking for building materials and technologies that could provide low-height housing industry with highspeed of construction, safety, ecological compatibility and financial efficiency.

The lightweight thin-walled cold-formed steel structures allow getting advantages that meet the requirements described above (Hancock 1997; Hartmut Pasternak, Ermopoulos 1995; Pekoz 1987). Due to some reasons in Russia there are no current norms (SP 16.13330.2011) that could be applied by engineers who design houses using the cold-formed steel structures. In this area a number of Doctoral theses have been defended in the recent years in Russia (G. I. Belyy, D. V. Kuzmenko, A. R. Tusnin, I. V. Astahov). Theoretical research and laboratory tests were done only for specific types of thin-walled cross-sections.

Jyrki Kesti made a major contribution to the development of local and distortional buckling of perforated steel wall studs (Espoo, 2000). Today thinwalled cold-formed steel structures are widely used in the Finnish building area. Experience of the Finnish engineers could help Russian scientific community to understand more exactly the behavior of such structures and the appropriate European norms (EN 1993-1-3).

Summary of the research described below concerns reticular-stretched thermo-profiles. Reticular-stretched thermo-profile is a new type of thin-walled cross-sections that found its place on the Russian market.

\section{General}

As object of research reticular-stretched thermoprofiles and their joints were analysed (see Figure 1). The following profiles are discussed:

1. Specimen S1 (stud) - АИ ТСc 200-45-2.0;

2. Specimen S2 (rack) - АИ ПН 200-50-2.0.

Steel used for specimen production has the following parameters:

1. Steel grade S350GD (yield strength not less than $350 \mathrm{H} / \mathrm{mm} 2)$;

2. Coating mass, $350 \mathrm{~g} / \mathrm{m} 2$;

3. Coating thickness, 25 microns.

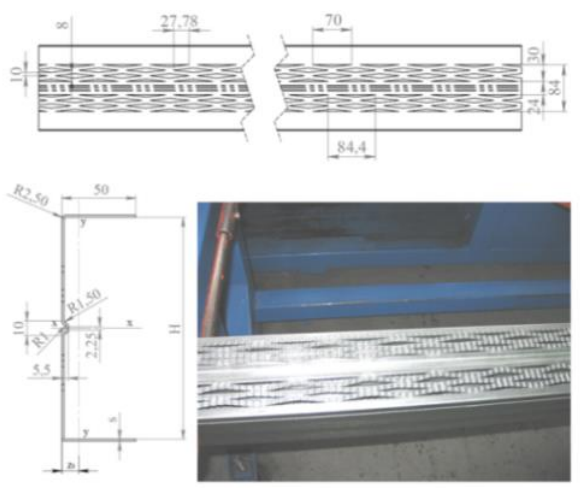

Fig. 1. Reticular-stretched thermo-profiles.

The research goal was to develop theoretical rationale for the usage of reticular-stretched thermo-profile throughout buckling and shear strength analysis based on the laboratory tests. 
Research tasks:

1. Laboratory tests:

- Compression test;

- Shear resistance test of stud-to-rack joint.

2. Numerical modelling (FEM):

- Buckling analysis;

- Shear resistance analysis of stud-to-rack joint.

3. Comparison of results.

Description and results of tests and numerical investigation are summarized below.

\section{Experimental investigations}

During experimental investigations the following tests were carried out:

- Compression test;

- Shear resistance test of stud-to-rack joint.

This paper describes parameters and results for some part of compression tests and shear resistance test of studto-rack joint. Tests were carried out in the Sheet Metal Centre at HAMK, using contemporary laboratory stand (Instron 3250), in May 2013.

\subsection{Compression test}

Compression test parameters are described below (see Figure 2, A).

1. Test specimen:

- C-shaped thermo-slotted profiles АИ ТСс 20045-2.0, web height $200 \mathrm{~mm}$, flange width $45 \mathrm{~mm}$, steel thickness $2.0 \mathrm{~mm}$;

- Total length of the test specimen $1000 \mathrm{~mm}$;

- The ends of specimen are cut using a circular metal saw (the ends will not be machined);

- Support blocks (thickness $40 \mathrm{~mm}$; edge is positioned $3 \mathrm{~mm}$ from the end of the profile) made of wood are placed inside the profile at the ends.

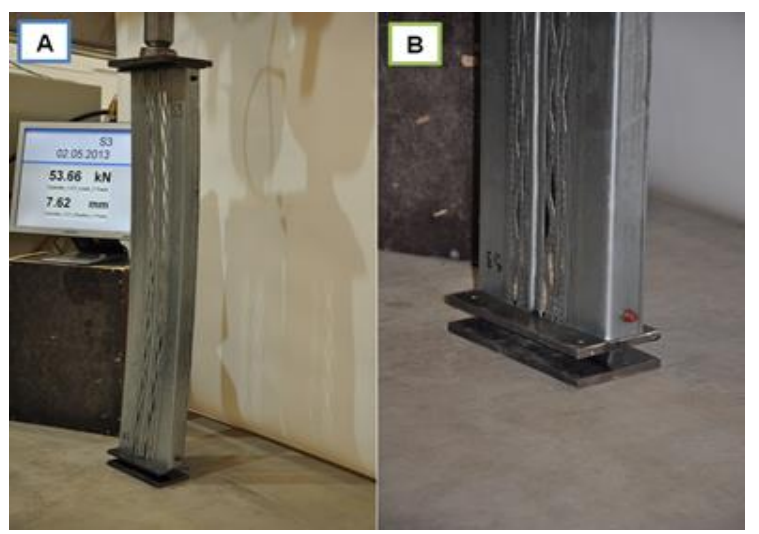

Fig. 2. Compression test (A - specimen S3; B - hinged support).

2. Test arrangement:

- The lower end of the specimen is placed on a hinged support made of steel (see Figure 2, B);

- The load of a hydraulic cylinder is applied through a thick steel plate to the upper end of the specimen.
3. Test procedure:

- The specimen is loaded using the displacement control until the failure of the specimen;

- The loading rate is $3 \mathrm{~mm} / \mathrm{min}$;

4. Test results:

- Buckling force.

\subsection{Shear strength test of stud-to-rack joint}

Shear strength test parameters are described below. Drawing of the joint is presented below (see Figure 3 ).

1. Test specimen:

- Stud: the same profile type as in the compression test of length $350 \mathrm{~mm}$;

- Rack: АИ ПН 200-50-2.0, U-shaped thermoslotted profile of length $600 \mathrm{~mm}$, web height $200 \mathrm{~mm}$, flange width $50 \mathrm{~mm}$, steel thickness $2.0 \mathrm{~mm}$ (the rack profile is press-braked on site and does not have thermal slots in web);

- The flanges of the stud are fixed with 4+4 selfdrilling screws ESSVE Wafer head screw 'Non-Head' Zinc drillpoint $4.8 \times 16$ to the flanges of the rack.

2. Test arrangement:

- The stud is fixed to the head of the hydraulic cylinder;

- The rack will be fixed rigidly to the test frame.

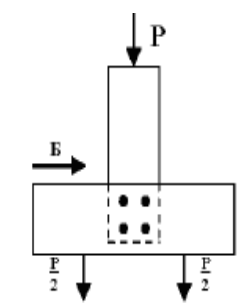

b

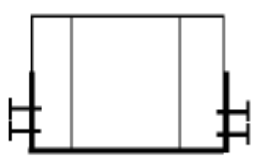

Fig. 3. Stud-to-rack joint. Scheme.

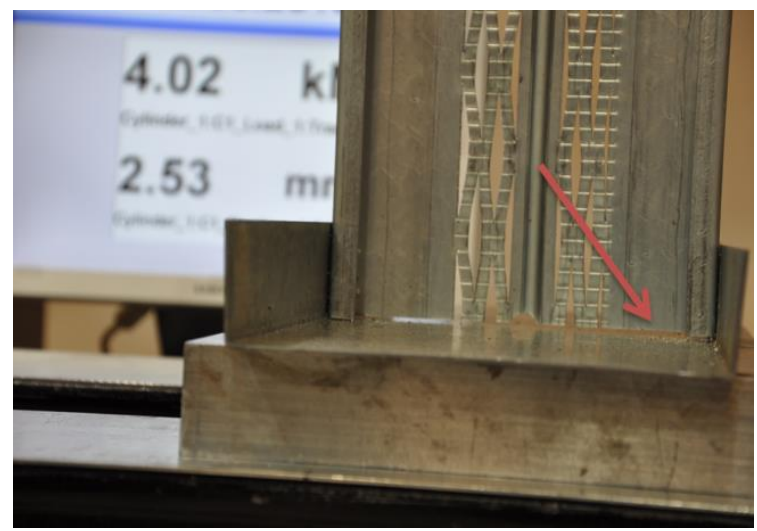

Fig. 4. Stud-to-rack joint. Clearance (app. 2.5mm).

3. Test procedure:

- The specimen is loaded using the displacement control until the failure of the specimen;

- The loading is rate $1.5 \mathrm{~mm} / \mathrm{min}$

4. Test results:

- Shear strength of the self-drilling screws. 


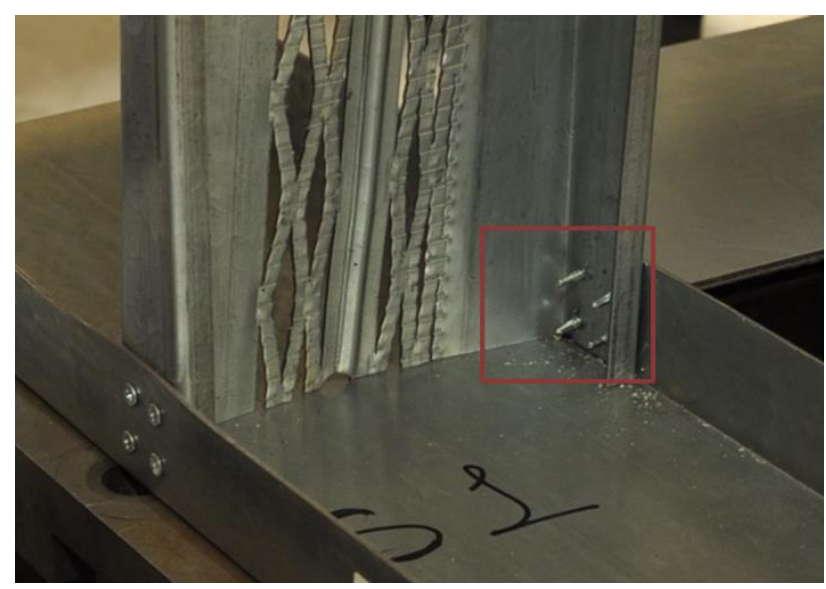

Fig. 5. Stud-to-rack joint. Bearing failure of screws.

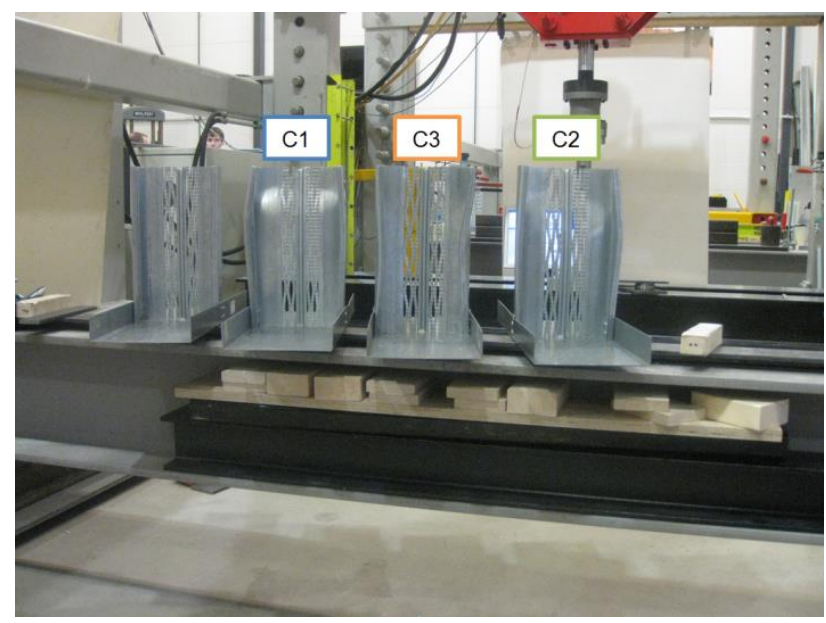

Fig. 6. Stud-to-rack joint. Specimen C1 ...C3.

\subsection{Test results}

Test results are shown in Figures 7-9 and Table 1.

Compression tests were carried out with 4 specimen, but specimen S3 more correctly describes the behavior of the hinged profile (see Figure 2). Resulting force that should be obtained is buckling force (Gioncu 1994). On the stress-strain diagram (see Figure 7) one could see that buckling failure is achieved at app. $54 \mathrm{kN}$. Buckling mode is one half wave of the sinusoid. But anyway some strange behaviour of the profile is shown before: short downfall of the current load. This stage demonstrates that firstly profile behaves like under semi-rigid boundary conditions, then abrupt crash sound and profile behaviour is like that of the hinged one.

Figure 8 demonstrates common stress-strain diagram for self-drilling screws joint (specimen number $\mathrm{C} 1$ ) when the last one is in shear. It should be said that real practice does not allow for stud-to-rack joints to have clearance between each member of the connection that one could see in Figure 4. Only for the purpose of the shear strength test of stud-to-rack joint a small clearance was left (app. $2.5 \mathrm{~mm})$

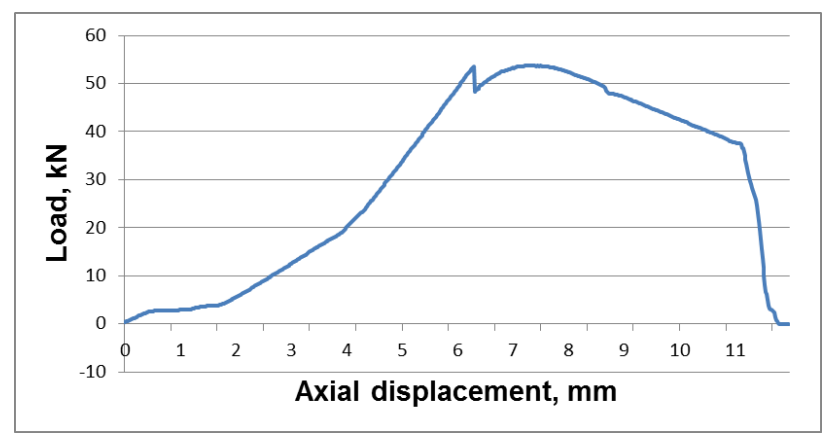

Fig. 7. Compression test diagram (S3).

Each joint in shear behaviour goes through the following stages:

- The first stage (A-B) demonstrates that all the clearances (not only the one that is described above) are got through;

- The second stage demonstrates elasto-plastic strain (B-C);

- The third stage (C-D) is noted by the yield segment of the diagram, strengthening, bearing failure of the sheet and achievement of the ultimate strength (point D);

- The forth stage (after point D) - crushing of the joint. At the higher load level the end of the stud contacts the rack profile placed on the rigid base.

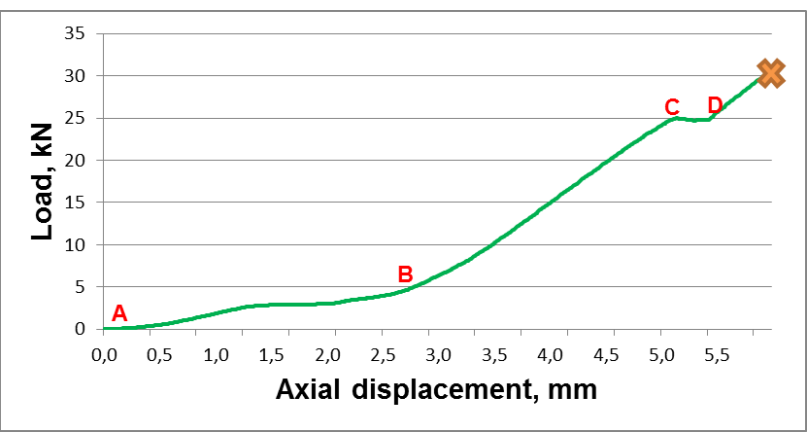

Fig. 8. Shear strength test diagram $(\mathrm{C} 1)$.

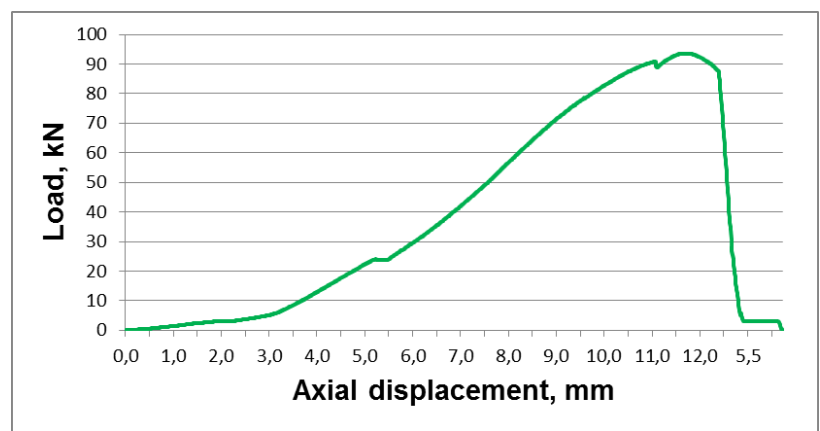

Fig. 9. Shear strength test diagram (C2).Full edition. 
Table 1. Tests results

\begin{tabular}{lcc}
\hline $\begin{array}{l}\text { Type of profile/ } \\
\text { Specimen number }\end{array}$ & Shear strength & Compression test \\
\hline & $\begin{array}{c}\text { Ultimate } \\
\text { breaking load, } \\
\mathrm{kN}\end{array}$ & $\begin{array}{c}\text { Buckling force, } \\
\mathrm{kN}\end{array}$ \\
\hline АИ ТСc 200-45-2,0 (S3) & - & 53.82 \\
АИ ТСc 200-45-2,0 (C1) & 24.95 & 90.82 \\
АИ ТСс 200-45-2,0 (C2) & 23.93 & 92.99 \\
АИ ТСс 200-45-2,0 (С3) & 24.37 & 99.88 \\
\hline
\end{tabular}

\section{Numerical modelling (FEM)}

Numerical modeling of thin-walled cross-sections and their stud-to-rack joint was done with contemporary analysis software (SCAD Office and Lira) (Slivker 2005) using finite element method (FEM). FEM-model parameters were the same as for the tests described above. During the modeling process the thin-walled profile based on shell- and bar-elements and joint based on solid-elements were created and buckling/shear analysis tasks showed good results (see Figure 10).
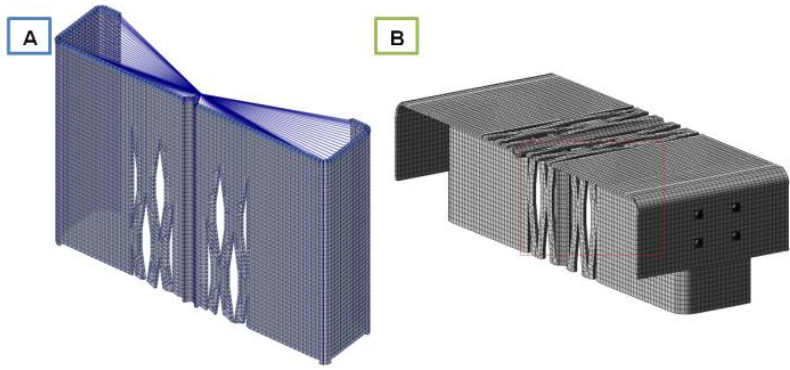

Fig. 10. FEM-model of thin-walled thermo-profile (A, shellelements) and joint (B, solid-elements).

\subsection{Buckling analysis}

Numerical modelling and buckling analysis of one meter thin-walled profile were carried out using FEMsoftware SCAD Office.

FEM-models for buckling analysis have characteristics described below.

Quantitative characteristics of shell-element models:

- Number of nodes - 27,485;

- Number of elements - 29,519;

- Finite element dimensions $-3 \mathrm{~mm}$.

Quantitative characteristics of bar-element models:

- Number of nodes - 11;

- Number of elements - 10;

- Finite element dimensions - $100 \mathrm{~mm}$.

Point load $(80 \mathrm{kN})$ was applied to the flexural center (FC) and points nearby to justify different types of profile deformation. It was shown that when load point is situated before FC $(6.0,9.0 \mathrm{~mm}$ from the outside surface of the web) thin-walled profile flexures inside itself (see Figures 2, A and 11, C together) and the difference between test and FEM-modelling results are equal to 0.33 and $3.75 \%$, accordingly.

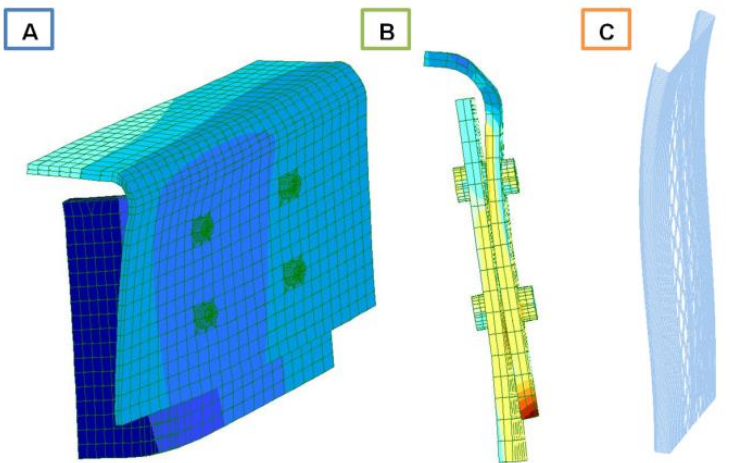

Fig. 11. FEM-model. Strain-stress state of screws connection $(\mathrm{A}, \mathrm{B})$ and thin-walled profile $(\mathrm{C})$.

The profile behaves differently when the load point is situated after FC $(11.5 \mathrm{~mm}$ from the outside surface of the web) (Kretinin, Krylov 2008). The thin-walled profile flexure outside itself. That is why the difference between test and FEM-modelling results is bigger and is getting up to $6.03 \%$.

FEM buckling analysis results are shown in Table 2.

\subsection{Shear strength analysis}

Numerical modelling and shear strength analysis of the screw joint were carried out using FEM-software Lira.

FEM-model for shear strength analysis has characteristics described below.

Quantitative characteristics of solid-element model:

- Number of nodes - 94,659;

- Number of elements - 62,736;

- Finite element dimensions $-3 \mathrm{~mm}$.

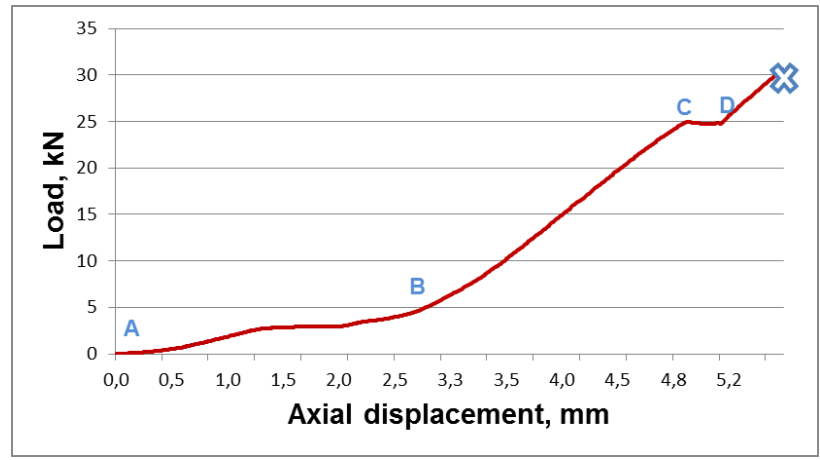

Fig. 12. FEM-modelling. Shear strength diagram.

As for screw connection, it was decided to model it using two-node FE with unilateral elastic constraint between the nodes.

Point load was applied to the flexural center (FC) step by step $(5.0,10.0,15.0,20.0,25.0,30.0 \mathrm{kN})$.

Real bearing failure of the screw connection takes place due to crush of the element material under load that is equal to $25 \mathrm{kN}$ (see Figure 12). One could see on the FEM-model that the main stress of steel near the connection place is getting up to $335 \mathrm{MPa}$ (more than yield strength of the steel, accordingly to table $3.1 \mathrm{~b}$ Eurocode 3 Part 1-3). Thereby, large plastic deformations happen and round screw hole changes to oviform (see Figure 13). 

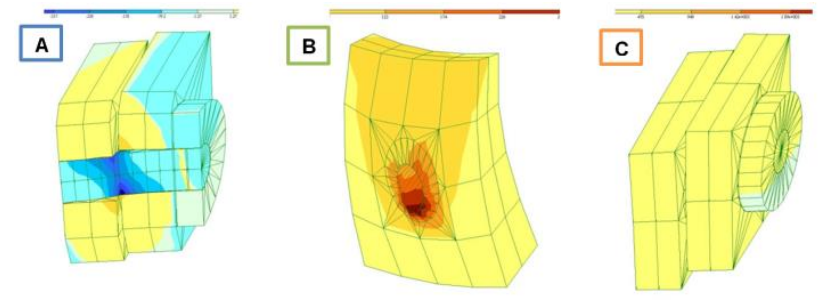

Fig. 13. Shear strength test diagram (C2).Full edition FEMmodel. Strain-stress state (A - section view; B - flange; $\mathrm{C}$ - screw connection).

Table 2. FEM analysis results

\begin{tabular}{|c|c|c|c|c|c|}
\hline \multirow[t]{2}{*}{$\begin{array}{l}\text { Type of profile/ } \\
\text { Specimen number }\end{array}$} & \multirow[t]{2}{*}{$\begin{array}{c}\text { Shear } \\
\text { strength } \\
\text { test }\end{array}$} & \multirow{2}{*}{$\begin{array}{c}\text { Shear } \\
\text { strength } \\
\text { analysis }\end{array}$} & \multirow{2}{*}{$\begin{array}{c}\text { Compression } \\
\text { test }\end{array}$} & \multicolumn{2}{|c|}{$\begin{array}{l}\text { Buckling } \\
\text { analysis }\end{array}$} \\
\hline & & & & Shell & Bar \\
\hline & \multicolumn{2}{|c|}{$\begin{array}{c}\text { Ultimate breaking } \\
\text { load, } \mathrm{kN}\end{array}$} & \multicolumn{3}{|c|}{ Buckling force, $\mathrm{kN}$} \\
\hline АИ ТСс 200-45-2,0 (S3) & - & - & 53.82 & 55.83 & 6,83 \\
\hline АИ ТСс 200-45-2,0 (C1) & 24.95 & 25.0 & - & - & - \\
\hline
\end{tabular}

\section{Conclusions}

Results of experimental investigation on the behavior of thin-walled cross-sections by compression (buckling analysis) and shear strength of their joints have been reported. For both tests numerical analysis was carried out including bar/shell finite elements for compression and solid finite elements for shear strength analysis.

Compression bar buckling has resulted in the axial failure of profile specimens S3 at a buckling force $53.82 \mathrm{kN}$. Results of numerical analysis (shell finite elements) differ from compression tests by about $4 \%$. Bar finite element analysis show slightly worse results that differ from the tests by about $22 \%$. The analysis clearly demonstrated that the existing design guidelines for thinwalled cross-section modeling by bar finite elements are not exact and could be used only taking into account extra safety factor -1.2 .

Bearing capacity of the screw connection C1 (four screws on each profile flange) is equal to $24.95 \mathrm{kN}$ and arithmetic mean value for three specimens $(\mathrm{C} 1 \ldots \mathrm{C} 3)$ is about $24.42 \mathrm{kN}$. Real bearing failure of the screw connection takes place due to crush of the element material. Results of numerical analysis (solid finite elements) differ from shear strength tests by about $2 \%$.

Summary of the investigations should be taken as a step to apply finite element method for modelling profile behaviour without real tests.

\section{References}

Astakhov, I. V., 2006. Prostranstvennaia ustoichivost' elementov konstruktsii iz kholodnognutykh profilei, Dissertation, St.-Petersburg, 123 p.

Bayan, A. A.; Sariffuddin, S.; Mohd, H. O., 2011. Finite Element Analysis of Cold-formed Steel Connections. International Journal of Engineering, (IJE), 5 (2), pp. 55-61.

Belyi, G. I., 1983. Raschet uprugoplasticheskikh tonkostennykh sterzhnei poprostranstvenno-deformiruemoi scheme.
Stroitel'naia mekhanika sooruzhenii: Mezhvuz. temat. sb. tr, LISI, 42, pp. 40-48.

Cheng, Y.; Schafer, B.W., 2007. Simulation of cold-formed steel beams in local and distortional buckling with applications to the direct strength method. Journal of Constructional Steel Research, 63 (5), pp. 581-590. http://dx.doi.org/10.1016/j.jcsr.2006.07.008

EN 1993-1-3, Design of Steel Structures: Cold-formed thin gauge members and sheeting.

Gioncu, V., 1994. General theory of coupled instabilities. ThinWalled Structures, 19, pp. 2-4. http://dx.doi.org/10.1016/0263-8231(94)90024-8

Gordeeva, A. O.; Vatin, N. I., 2011. Magazine of Civil Engineering, 3(21), pp. 36-46.

Hancock, G.J., 1997. Light gauge construction. Progress in Structural Engineering and Materials, pp. 25-26. http://dx.doi.org/10.1002/pse.2260010107

Hartmut, P. John, E., 1995. Design of steel frames with slender joint-panels. Journal of Constructional Steel Research, 35 (2), pp. 165-187. http://dx.doi.org/10.1016/0143-974X(94)00034-F

Kesti, J., 2000. Local and distortional buckling of perforated steel wall studs. Dissertation for the degree of Doctor of Science in Technology, Espoo, 101p. + app. 19 p.

Kolesov, A. I.; Lapshin, A. A.; Valov, A. V., 2007. Sovremennye metody issledovaniia tonkostennykh stal'nykh konstruktsii. Privolzhskii nauchnyi zhurnal, 1, pp. 28-33.

Kretinin, A. N.; Krylov, I. I., $\quad 2008$. Osobennosti raboty tonkostennoi balki iz gnutykh otsinkovannykh profilei. Izvestiia vysshikh uchebnykh zavedenii, Stroitel'stvo, 6, pp. 1-11.

Kriksunov, E.Z.; Perel'muter, A.V.; Urchenko, V.V., 2010. Proektirovanie flantsevykh soedinenii ramnykh uzlov. Promyshlennoe i grazhdanskoe stroitel'stvo, 2, pp. 33-37.

Pekoz, T., 1987. Development of a Unified Approach to the Design of Cold-formed Steel Members. Research Report CF 87-1, American Iron and Steel Institute.

Peleshko, I. D.; $\quad$ Urchenko, V. V., $\quad 2009 . \quad$ Optimal'noe proektirovanie metallicheskikh konstruktsii na sovremennom etape (obzor rabot). Metallicheskie konstruktsii, 15, pp.13-21.

Perel'muter, A. V.; $\quad$ Kriksunov, E. Z.; $\quad$ Karpilovskii, V. S.; Maliarenkok, A. A., 2009. Integrirovannaia sistema dlia rascheta i proektirovaniia nesushchikh konstruktsii zdanii i sooruzhenii SCAD Office. Novaia versiia, novye vozmozhnosti. Magazine of Civil Engineering, 2, pp.10-12.

Rasmussen, K. J. R., 2009. Experimental investigation of localoverall interaction buckling of stainless steel lipped channel columns. Journal of Constructional Steel Research, 65, pp. 1677-1684. http://dx.doi.org/10.1016/j.jcsr.2009.04.025

Schafer, W.; Pekoz, T., 1998. Computational modeling of coldformed steel: characterizing geometric imperfections and residual stresses. Journal of Constructional Steel Research, 47, pp. 193-210. http://dx.doi.org/10.1016/S0143-974X(98)00007-8

Shatov, D. S., 2011. Magazine of Civil Engineering, 3(21), pp. 32-35.

Slivker, V. I., 2005. Stroitel'naia mekhanika. Moskow: ASV, $736 \mathrm{p}$.

Smaznov, D.N., 2011. Konechno-elementnoe modelirovanie stoek zamknutogo secheniia iz kholodnognutykh profilei. Nauchno-tekhnicheskie vedomosti Sankt-Peterburgskogo gosudarstvennogo politekhnicheskogo universiteta, 123, pp. 334-337.

SP 16.13330.2011, Steel structure, M. Minregion razvitiya RF, 2011, $171 \mathrm{p}$. 
Tusnin, A. R., 2009. Chislennyi raschet konstruktsii iz tonkostennykh sterzhnei otkrytogo profilia. Moscow: Izd-vo ASV, $143 \mathrm{p}$.

Vatin, N. I.; Sinelnikov, A. S., 2013. Strength and Durability of Thin-Walled Cross-Sections. Design, Fabrication and Economy of Metal Structures. International Conference Proceedings, Miskolc, Hungary, April 24-26, pp.165-170.

Vatin, N.I.; Popova, E.N., 2006. Termoprofil'v legkikh stal'nykh stroitel'nykh konstruktsiiakh. St.-Petersburg: Izd-vo SPbGPU, $63 \mathrm{p}$.

Winter, G., 1952. Light Gauge (Thin-Walled) Steel Structures for Building in the U.S.A. preliminary publication. 4th Congress of the International Association for Bridge and Engineering, $524 \mathrm{p}$.
Yu, Wei-Wen, Wolford, D. S.; Johnson, A. L., 1996. Golden Anniversary of the AISI Specification, 13 International specialty conference on Cold-Formed Steel Structures, St. Louis, MO, 1-3, pp. 5.

Zhmarin, E.N., 2012. Mezhdunarodnaia assotsiatsiia legkogo stal'nogo stroitel'stva. Internet Journal "Construction of Unique Buildings and Structures", 2, pp. 27-30.

\section{Acknowledgements}

The experimental work was commented by Arto Ranta-Eskola, director of research, Rautaruukki Oyj (Finland). The authors also gratefully acknowledge the helpful comments and suggestions of the reviewers, which have improved the presentation. 